\title{
Chasing the Yellow Demon
}

\section{IAN JOHNSON}

Author's note: A few years ago, I read David Johnson's Spectacle and Sacrifice: The Ritual Foundations of Village Life in North China. ${ }^{1}$ The book immediately caught my attention because it dealt with parts of China that I know well: southern Hebei and eastern Shanxi provinces, where I was conducting research for a new book. Johnson describes festivals that helped bind together communities, and in several cases had information showing that some of them had been revived after the Cultural Revolution.

One, particularly, seemed noteworthy: Guyi Village in the south of Hebei Province. This is near the steel-making city of Handan and one of the most polluted parts of China. I had been there several times and was fascinated with the idea that this area could also be home to elaborate, multi-day rituals that seemed otherwise not to exist in North China. According to Johnson's informants, local scholars had visited the village in the 1990s and seen exciting performances of Zhuo Huanggui, or Chasing the Yellow Demon, an exorcistic purging ritual performed at the end of the fifteen-day Chinese New Year's festival. I contacted local officials and academics, who were unsure if the ritual would be performed again. No one, it seemed, had been out to the village in years. So in mid-February 2014, I set off to see if anything was left of these complex performances. ${ }^{2}$

\section{The Transformation}

A S THE TOWN BELL tolled the 3:00 a.m. yinshi watch, four men entered the crowded courtyard of the Li Family Ancestral Shrine. They nodded at four younger men, who broke away from a large group and followed their elders, two into one side room and two into another. The young men took seats as the older men unpacked their kits, pulling out small bottles of makeup and thin paintbrushes. Their job: to transform the young workers into sacred vigilantes. The crowd of about one hundred onlookers had been waiting for this moment. Murmuring quietly, they shoved their way into the two little rooms to watch the conversion.

In one of the rooms, the two young men tied a plain cotton kerchief over their heads so their hair lay flat. They folded their arms on their chests, staring impassively against the far wall. The older men bent over, painting their faces with swirling black and white concentric lines that started on their noses and worked out. They used thin Chinese writing

Ian Johnson (iandjohnson@gmail.com) is an independent writer based in Beijing.

${ }^{1}$ David Johnson, Spectacle and Sacrifice: The Ritual Foundations of Village Life in North China (Cambridge, Mass.: Harvard University Press, 2009).

${ }^{2}$ This article is drawn from research made for my forthcoming book, The Souls of China: The Return of Religion after Mao (New York: Pantheon, 2017). 
brushes, dipping them carefully into the paint and confidently drawing the lines, each brushstroke revealing the demon within (see figure 1).

Their audience was made up of villagers and a few visitors from nearby cities. The former stood quietly in the background, watching as the familiar event unfolded. The tourists were much more earnest. They had the gear and mentality of people on a safari. They blasted off countless shots, their cameras' fat memory chips allowing them to shoot at will. The older men affixed wigs of grey and tan straw-like hair on the younger men's heads, making them look depraved and violent (see figure 2). The cameras whirred. An old man finished painting one line and sat back to look at his work. Chucka-chucka-chucka-chucka. He dipped his brush into a jar. Tshick-tshicktshick-tshick-tshick. A young man stripped off his woolen plaid shirt and put on a yellow silk vest. Gzzz-gzzz-gzzz-gzzz-gzzz. After half an hour, the old men leaned back and looked at their charges. They were called the Great Demon (dagui) and the Second Demon (ergui). For a minute, no one took a picture. These were convincing demons, fierce and exotic, strange apparitions from another world. Then the shutters clattered and soon the pictures were being sent out across China on social media.

The men were preparing for Zhuo Huanggui (Chasing the Yellow Demon), a play that people in the village of Guyi perform most years as part of a series of events on Yuanxiao, or the last day of Chinese New Year. Yuanxiao is often translated as the "Lantern Festival," but the Chinese means something else: first night, or primal night, a much more fitting name that harkens back to the festival's origins as a time of purging and exorcism before the new year unfolds.

Here, about 300 miles southwest of Beijing, that rougher tradition was still palpable. The play was part of an elaborate two-day festival of exorcistic plays called Nuo. Almost

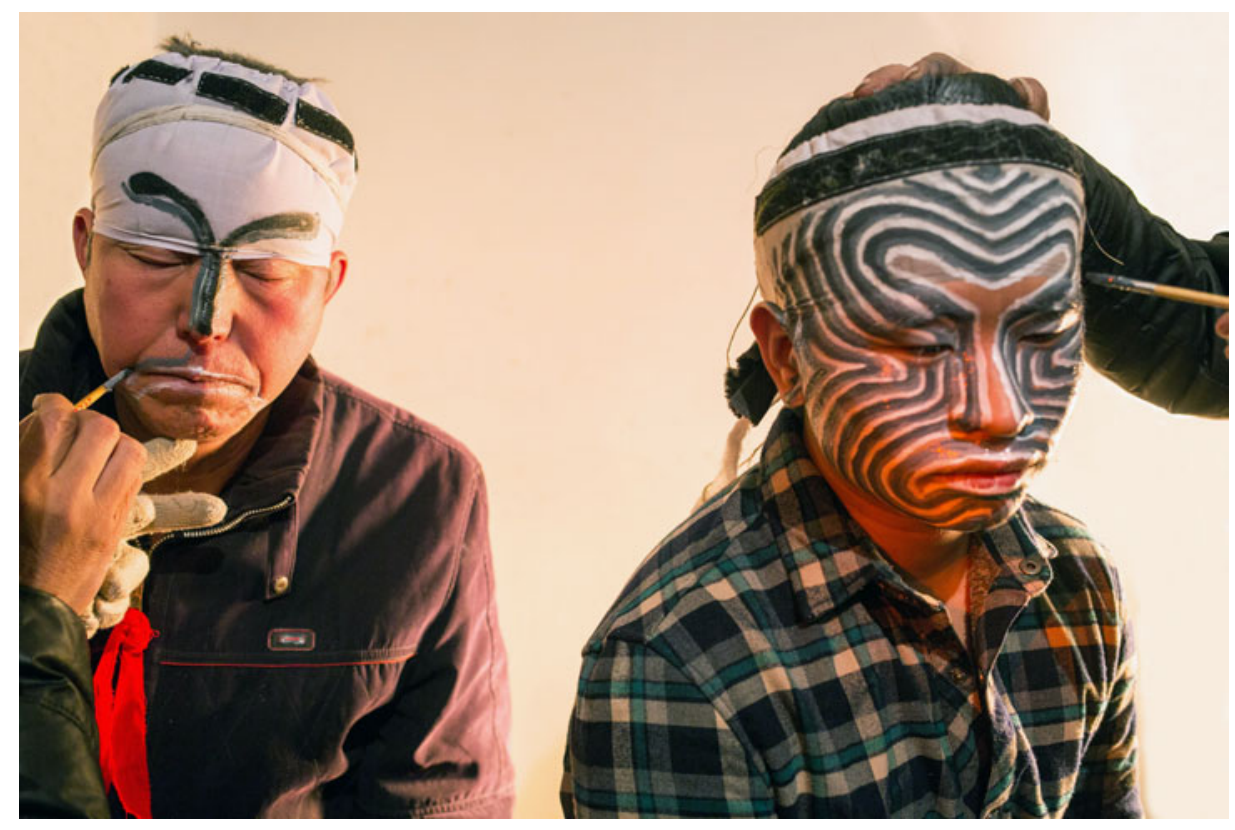

Figure 1. The Greater and Second Demon being made up. Photo by Sim Chi Yin/ VII Photo Agency. 


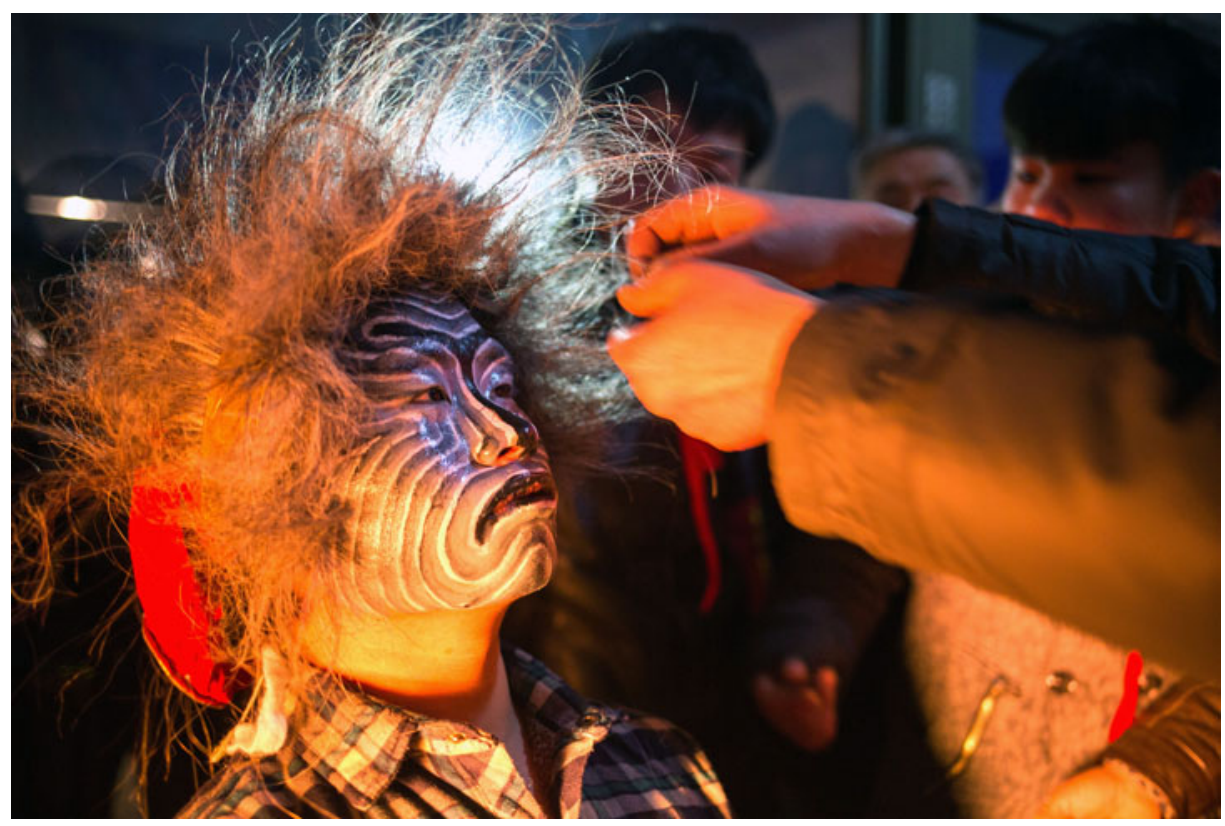

Figure 2. Preparing the Greater Demon's hair. Photo by Sim Chi Yin/VII Photo Agency.

everyone in the village participated in some way, but the key players, like the young demons, were members of families that had provided actors for the piece for generations. It was like the passion plays still performed in central European villages, except that those events are sleek parts of a carefully calibrated tourist industry, explained on professional Internet pages and with tickets sold out in advance. Here was something less polished and more precarious, a tradition that survived even though the village seemed to get little in return.

In the past, the benefits were probably clearer. The Yellow Demon is drawn from a local myth about a being so monstrous that he had violated the precepts of filial piety. Violating them meant negating civilization; the demon was society without rules-a beast that had to be slayed. In his 1998 study of the rituals, the Handan-based historian and folk religion scholar Du Xuede wrote that the Yellow Demon also incarnated more concrete problems facing villages, such as flooding, drought, insect plagues, and illness. ${ }^{3}$ Once the Yellow Demon was found, the two good demons would lead a gang of local young men and chase him through town until, exhausted, he would be handed over to Yama, the god of the underworld. At some point in the past this would have been a grim reminder to people to keep social order, but also a chance to bind the community into something tighter than a grouping of neighbors. But what did it mean today?

${ }^{3}$ Du Xuede, Yan Zhao Nuo wenhua chutan [Preliminary explorations into the Nuo culture of Yan and Zhao] (Lanzhou: Gansu renmin chubanshe, 1998), 2. 


\section{The Scouts Depart}

In the next room were the two other young men. They were being transformed into Tanshen, or Scouts. They were to spend the rest of the night riding every pathway through the village trying to find the Yellow Demon, and then turn him over to the two good demons. While the good demons exuded testosterone and anger, the Scouts were impassive, as if they knew the outcome with grim certainty: no one could escape their relentless pursuit.

The Scouts were being made up in an even more elaborate fashion (see figure 3). Their faces were first covered in white makeup and their eyebrows highlighted with black paint. Then the makeup artists - often their fathers or uncles, who had played the role before them-painted thin whiskers that made them look like hares. Their lips were red and pouting, and a red dot was painted on their forehead.

But it was their clothes that set them apart. First they pulled on thick black trousers and heavy felt boots, and then padded-cotton tunics of green with white trim. Broad sashes held the heavy clothing in place. But this was just the first layer, which no one would see. On top came a brilliant satin and silk brocaded uniform. One Scout wore black and gold, the other white and blue. The hand-stitched trim must have taken hundreds of hours of work: dragons, angry faces, and auspicious characters jumped off the fabric, reminding people that these were gods come to life-a morality play that would take place not on a stage but in the streets of their village. And then came a stiff piece of cloth, hinged in the middle and with a hole for the head. It hung over the Scouts like matted armor. That was not by accident- the men were dressed like generals in a traditional opera. The final touch were four hand-stitched silk flags on little poles that were fixed into the back of each of the Scouts' uniforms. The flags stuck up behind their heads like a peacock's plumage. Finally, each man donned white gloves, which matched their white faces. They looked like living dolls.

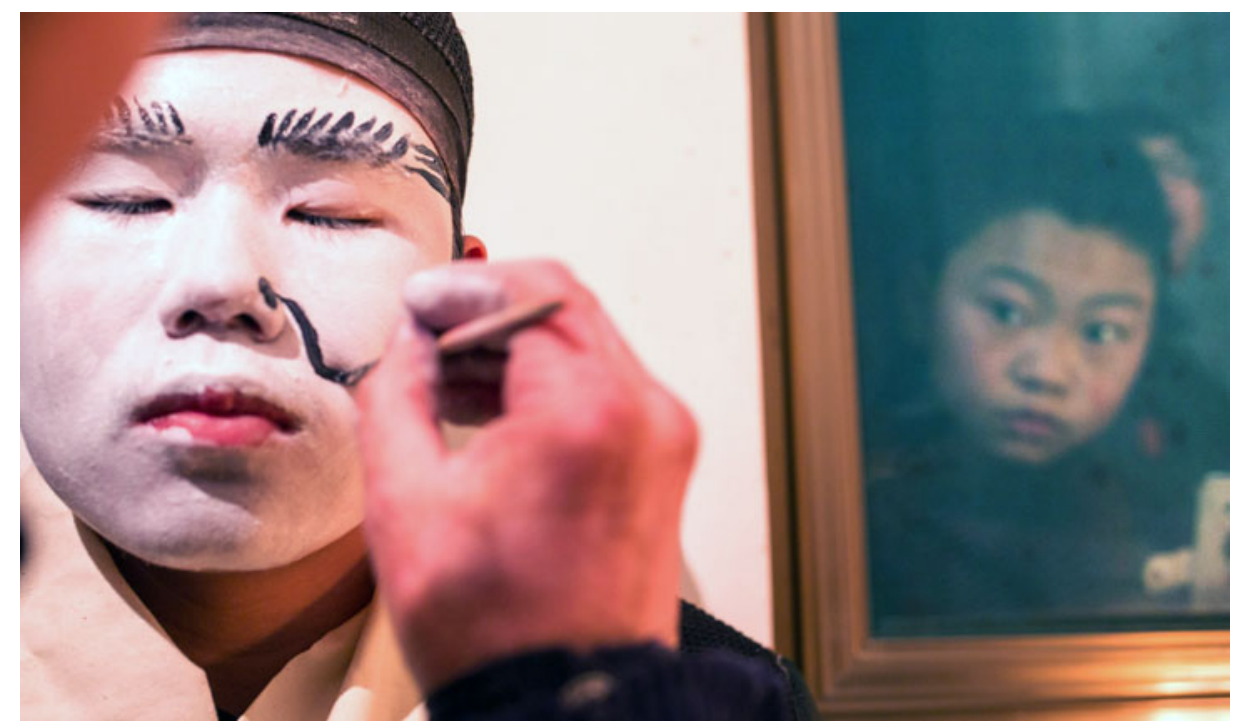

Figure 3. Painting one of the Scouts. Photo by Sim Chi Yin/VII Photo Agency. 
It was now 4:00 a.m., and the Scouts sat expressionless on the edge of a bed, waiting for the hunt to begin. One was Lü Qiang, a twenty-six-year-old worker in a local smelter. His father, who had played the role before him, had made him up. This was the young man's fifth time to play a Scout. He was impassive, and his answers monosyllabic. Next to him was Lin Jianxiong, a twenty-one-year-old, slightly pudgy and lethargic. He looked up slowly when addressed but kept his mouth shut. They had been coached well; this was a ritual, and they were not to ruin the solemn atmosphere by jesting or joking, or answering questions about why they did this and what it meant to them.

The Scouts eventually made their way out into the cold night air. Several older men set a pile of straw on fire. They used a stick to lift up the strands, making it easier for the fire to catch. When the flames were about two feet high, with the crowd shouting and the cameras blasting, the Scouts ran through the courtyard and jumped over the fire. The flames licked at their clothes, but they passed unharmed. Purified, they walked outside to two donkeys that would carry them on their rounds.

Lü mounted first and set off. I decided to follow Lin, the lethargic one; maybe I could keep up with him and watch the Yellow Demon be captured. Lü had gone west down the main alley through town. Lin headed east. An older man led the donkey at a brisk pace, sometimes jogging to encourage the animal into a canter.

When I had arrived in Guyi the day before, the fields had glistened with melting snow, and the dirt roads had been muddy ruts. Night had frozen the slush into icy grooves, but the donkey was sure-footed and the men moved quickly. I jogged to keep up.

Strung across the street above us were banners exhorting people to follow the precepts of filial piety: "Father's affection and mother's love leads to prosperity and long life," "Selflessness leads to a greater world," and "Honoring your mother and father is like respecting heaven." Each time the Scout passed one of these banners, he had to bow so that the flags sticking up from his back would not get snagged. It seemed like he was honoring the ideas, showing obeisance to the great beliefs of the past.

In front of him was the full moon - the first of the new year. It reflected off the ice and the Scout's white uniform. It was bright like a second sun, washing us in its cold light: a clear, silent herald. We trotted toward it, heading away from Guyi's temples and rough homes.

The edge of the village soon arrived, and with it the start of fields, frosted and hard. To our right were flatlands and then, half a mile away, a ridge. On it was the highway that twisted 800 miles through old mountain passes to the western metropolis of Lanzhou. We could see the lights of trucks and the odd car, but they made no noise, like fireflies winding through the murky hills.

The Scout doubled back and passed me. His face was severe, but he clutched the reigns lightly. I stopped to take a picture of the moon, turned around, and they were gone. I ran back down the road to the first intersection and looked down it. Nothing. I ran to the next street. Nothing. I jogged up and down a few more streets before giving up.

I got back to the Li Family Shrine just as the Great Demon and Second Demon were emerging to assume their role in the play. The men had stripped off their shirts and jackets. Their muscular chests were covered only by short yellow vests that were left open. They should have been cold, but they were young and energetic, and on a mission. They yelled as they jumped the fire and entered the street, leading a posse of young 
men waving willow branches. They screamed and shouted, waving their sticks as they barreled down the nearest alley. Some carried torches. It looked like a lynching.

The sun was slowly rising and the moon, now a sulfuric yellow, was setting. As I trudged down the street, I noticed a handbill prominently pasted to one of the village's old brick walls. It was handwritten in calligraphy on a yellow sheet of paper-a warning, issued by the Western Great District (xidashe), an amalgam of clans that had existed before the Communist takeover. All of these old political-religious structures had been eliminated after 1949, but now they seemed alive again, just like the rituals announced on the flyer:

\section{Public Notice:}

To the world's people, don't bully your parents, and don't forget the basic rule of being a child. If you are unfilial, the gods of the ten temples will not leave you alone. The two demons will chain and lock you at the southern stage, pull out your intestines and strip your skin. Good and evil in the end will be repaid. Why don't people respect their parents?

-Announcement of the Western Great District.

\section{The Village}

Guyi Village lies in the Taihang Mountains, a range running roughly from Beijing to China's fertile south. The mountains are not high, but they are rugged, and in ancient times were a barrier between the wheat-growing areas of the North China Plain that run east toward the ocean and the inland areas where many Chinese dynasties have had their capitals - Xi'an, for example, or Luoyang. For millennia, they have been a crossroads of myth and history, home to the matriarchal creator of human beings, Nüwa, and prized by military strategists for their narrow passes.

This puts Guyi at the center of Chinese civilization, but also in a part of the country that today is usually overlooked. There is no terracotta army, no grand temples, no ancient walled cities. It has no booming cities, no ports, and no hip urbanites. Instead, the area is now best known for its coal mines and steel factories that make its neighboring cities-Handan, Xingtai, and Shijiazhuang-some of the most polluted areas in China.

But as Johnson points out in his book, probably for as long as people have called themselves Chinese, they have lived in this region. ${ }^{4}$ It lies near the Zhuozhang River, which flows through a gap in the Taihang Mountains and into the Grand Canal, the great waterway built in ancient times to link the country's north and south. Just south of Guyi is the city of Anyang, where as far back as the fourteenth century BCE, the Shang dynasty took root. There, some of the earliest and most famous artifacts of Chinese history were produced: oracle bones, which had the first written Chinese characters, and eerily powerful bronze vessels, decorated with mythic beasts and monsters. On the map, Guyi is one dot among many, but this incredible population density

${ }^{4}$ Johnson, op. cit. note 1 . 
makes it important. As Johnson put it, this part of the map of China is "black with the names of villages. Truly this is village China."

Guyi is built on the eastern foothills of the Taihang range. To its south is Longhu River, which flows out of the mountains to the Nanming River. According to an unpublished local gazetteer from 2013, Guyi has 850 households and 2,943 people, and the total inhabited area is 7.5 square kilometers. The main occupation is agricultural, and farmers till 3,600 mu or 240 hectares, with wheat, corn, and millet the main products. ${ }^{6}$ The land is classified as fertile, and water supplies are adequate. The village bulges around the highlands and narrows as it follows the river. Or, as the local gazetteer explains: "It meanders along the river and looks like a fish, with its head to the west and tail to the east."7

Today, Guyi Village is relatively poor. Although statistics are not available for its per capita income, locals say that agriculture brings little income, so most able-bodied people between eighteen and forty-five work elsewhere as migrant laborers. But for much of its history, Guyi and its surroundings were prosperous-bedrock agricultural regions, strategically located along the trading routes through the Taihang Mountains. This gave it enough resources to stage the elaborate Nuo dramas.

Nuo is a loose category of dances, plays, and dramas that seem to have had an exorcistic function. The most common images of Nuo are of dancers with large wooden masks in the southern part of China. ${ }^{8}$ Du calls Guyi's form of Nuo "Hot Nuo Opera" (renuoxi). Some of the performances during the two days of Yuanxiao have the wooden masks typical of southern shows, but others perform with painted faces, such as "Chasing the Yellow Demon."9

Well into the twentieth century these were lavish affairs. Visitors came from miles around, with processions through the hills and villages. Johnson helps us mentally recreate this world, reminding us that our view of rural China has too often been filtered through the lens of the past century of upheaval, famine, and victimization. Many parts of rural China were places of wealth, and supported temples "with roofs of beautifully glazed tiles and walls painted the same dusty red as the imperial palaces, located in settings of considerable beauty away from villages and towns, from which they dominated the surrounding landscape like castles." 10

This also made me think about how we view the Chinese past. For much of the past century, a kind of vulgar Marxist analysis has held sway: that Chinese peasants were a faceless horde who lived in a simple world of drudgery and exploitation, capable of action only when driven by foreign invasion or outrageous abuse. But here was a world

\footnotetext{
${ }^{5}$ Ibid., 12 .

${ }^{6}$ In 1998, Du reported 700 households, a population of 2,700, and 3,628 mu in his study. Du, op. cit. note 3,7 .

${ }^{7}$ Guyicunzhi [Guyi village gazetteer], November 2013, unpublished. Agricultural statistics on p. 4, "meandering" quote on p. 15.

${ }^{8}$ See, e.g., the works of the ethnographer and historian Li Lan: Li Lan, "The Changing Role of the Popular Religion of Nuo (倠) in Modern Chinese Politics," Modern Asian Studies 45, no. 5 (2011): 1289-1311; Popular Religion in Modern China: The New Role of Nuo (Farnham, Surrey, UK: Ashgate, 2015).

${ }^{9}$ Du, op. cit. note 3, 3. Citing local tombstone inscriptions, Du estimates that the dramas have a history in Guyi of at least 500 years.

${ }^{10}$ Johnson, op. cit. note 1, 11-12.
} 
of complex imagination and sophisticated stagecraft, created by a creative people with substantial disposable income. And yet we know so little about it. We still do not know whether these villagers modeled their performances on real-life trials and official ceremonies, or whether official life was modeled on local religious traditions. Most of our understanding of China's past has come through the records set down by the Confucian elite, so of course the view is that local religious practice copied government rites.

But what if it was the other way around? Johnson forces us to ask if the elite might have been copying the rich, fantastical world of local religion, perhaps as a way to legitimize their rule. These thoughts reminded me of today's public campaigns against corruption or to tout high-minded Communist heroes worthy of emulation. These are morality plays, too, and they seem a lot closer to Guyi's theatrics than anything Marx wrote. In the end, who is copying whom?

\section{The Villagers}

Li Zengwang is a sixty-five-year-old farmer who heads the Great Western District. Mr. Li's job is to coordinate among the other two she in the village and to help organize the Yellow Demon play. His family has always had actors in key positions. When the Cultural Revolution ended and public religious traditions revived in the late 1970s and '80s, he performed under his grandfather's tutelage.

"My father couldn't do it," he told me when I went to visit him the day before the hunt started. "When he was a young man we had the Cultural Revolution and so he didn't learn anything. It was a big regret for him."

We met in the same rooms where the actors would be made up in a few hours. A typical ancestral shrine usually looks like a temple, made of wood, with curved eaves and a tiled roof. This one, however, looked exactly like a modern North China home: four rooms, made of concrete, one on each side of a rectangular, open-air courtyard. Li said the original ancestral shrine was torn down in the Cultural Revolution. These shrines were prime targets because they were a key pillar of traditional Chinese society. It was in these shrines that tablets were kept listing a family's ancestors. Everyone who belonged to the clan paid for the shrine's upkeep and came here to worship on holidays. It was a way of organizing society, something independent of the government-like the village districts, or the she. And so of course the shrines had to go. The modern state could have no competitors.

"They ripped it down and carted the wood away. The tablets were smashed," Mr. Li said. "This was a dark time."

After China launched economic and social reforms in the late 1970s, Mr. Li got the lot back and built the family's current home on it, putting in a few tablets that had survived the chaos. But the Li family were hardly disgruntled victims. They were part of the new order: in the living room were framed awards from the Communist Party to one of the family's children: "Outstanding Cadre," "Outstanding Communist Youth League Member," “Advanced Merit Award.” Like many of the most capable people in the village, they had been coopted into the governing system, but had their own ideas and values. 
Staging the play was a huge logistical undertaking, one that gave me great respect for Mr. Li and the others involved. Like other performances across China, these ceremonies made little use of Daoist or Buddhist clergy; none of the temples, for example, ever had permanent clergy, according to local people. It is unclear if some of these rituals were based on Daoist liturgy, but local people claim they have always been organized by lay people, just as it is today.

Even though I was focusing on one play, "Chasing the Yellow Demon," the events ran for two days. After the Yellow Demon was dispatched and harmony restored to Guyi, the villagers would stage half a dozen shorter plays, including several with the more typical wooden masks found in Nuo dramas. All of this had to be coordinated and financed.

In the best of times, this would have been a complex undertaking, but two problems added to Mr. Li's work. One was the effect of the tumult of the twentieth century. War with Japan and then the first thirty years of Communist rule meant that the plays had not been performed from about the 1940 s (no one was exactly sure) to $1987 .^{11}$ The high point of this forty-year gap was the Cultural Revolution. Guyi saw armed violence, with the gazetteer reporting that "many officials were driven to their death." 12 Performers also could not teach many skills, especially make-up, to their children. Much knowledge was lost. ${ }^{13}$

And when they were revived, only very old men were able to describe what they had experienced as very young men. Unlike many other villages nearby, Guyi was lucky because most of the scripts to the plays had survived. But how to perform it, how to inflect the speech, how to sing the words on the page, and even how to apply make-up - most of that was lost, forcing organizers to recreate their traditions.

Mr. Li said his second big problem is that village life is breaking up. Guyi lies in the center of China's great steelmaking centers, which hire young men away to work in mines, smelters, or coking factories, while women go to work in factories, as domestic help, or as cheap labor in the service industry. Construction and many other jobs are also on offer in the city of Handan, which is just an hour's drive away. From there it is just an hour by high-speed rail to the provincial capital of Shijiazhuang or two hours to Beijing.

Walking through town earlier that day, I saw a handbill advertising the sort of work on offer:

Wu'an City Quanhesheng Company, because of expansion plans, is looking for people to hand out advertising flyers. Requirements: age 20 to 45, no preference for male or female, no experience necessary, education level middle school. Package: base salary + performance bonus paid every six days + award money food supplement + food + lodging. The salary is 3,000 yuan and up.

It was not great work (roughly US $\$ 500$ a month), but more than the zero income the young person would make staying in Guyi as surplus labor-each household has about 0.3

\footnotetext{
${ }^{11}$ Du reports that the Nuo dramas were performed in 1953, 1964, 1987, 1990-92, 1995, and 1997. Du, op. cit. note 3, 12 .

${ }^{12}$ Guyicunzhi, op. cit. note 6, 33.

${ }^{13}$ Ibid., 13 .
} 
hectares of land. But this migration made staging the performance especially difficult. The 500 or so people who lived outside Guyi for fifty of the year's fifty-two weeks were key performers - the young people who had the stamina to charge around the village hunting the demon.

"In the past we spent more than a month to prepare," Mr. Li told me. "But now we just have a week or two."

"Were the performances now as good as in the past?" I asked.

"I have to say that the performers aren't as good as in the past. They just don't have the time, but they're good boys and pick it up quickly. They do their best."

\section{INTANGIBLE Heritage}

I wondered why they bothered. The government supports the play in a small way. Like many cultural practices that once were banned as superstition, the Nuo plays have now been declared "intangible cultural heritage." The term-known in Chinese by the abbreviation feiyi-was popularized by the United Nations Educational, Scientific and Cultural Organization and adopted by the government as a measure of officials' performance. As the government strives to promote its legitimacy as a supporter of Chinese culture, officials have been instructed to find and support these projects. Today, tens of thousands exist, with designations possible (in ascending bureaucratic order and prestige) by district, county, city, provincial, and national governments.

In Guyi's case, the play received national-level designation in 2006, during the first tranche of practices reviewed by the government. Mr. Li became the official "inheritor" (chuanchengren) of the practice. The heads of three other clans were made provinciallevel inheritors.

The monetary rewards are not huge. National-level intangible cultural heritage practices receive an annual award of 10,000 yuan, or about $\$ 1,800$, while provincial-level practices get 3,000 yuan. Sometimes inheritors can receive more money by participating in government-sponsored cultural events, and for some practices, such as calligraphy, teapot-making, and culinary skills, the designation can help increase prestige and result in a good income.

This did not seem to be the case in Guyi Village. Organizers told me that the event costs an estimated 50,000 to 60,000 yuan to stage. The village heads pool their government subsidies, which total 19,000, and the rest is paid by donors, such as local businesspeople, or sometimes the village government. ${ }^{14}$

The money is spent on the costumes and props, such as the swords and halberds, and the stage where the demon would be executed. The performers themselves receive no money. The only exception is the Yellow Demon, who gets 2,000 yuan.

So why perform? People overwhelmingly told me that they did this because it was part of their tradition and meant something to them. They did not believe that the

\footnotetext{
${ }^{14} \mathrm{Du}$ also observed in his 1990s surveys that the event was financed by villagers. See Du, op. cit. note 3, 13. In a subsequent telephone interview, Mr. Li said a local businessman paid the balance in 2015. In 2016, the village paid a subsidy of 20,000 yuan, with the balance made up by small donors.
} 
exorcistic rituals purged the town of evil, but they approached it with a solemnity that reminded me of lay members of a church — say, candle bearers or members of a choir.

Perhaps the most eloquent reply I received was from a man I met at one of the village's temples. He was a retired Communist Party secretary, and proud of the plays' revival. For him, it was about honoring the village's ancestors, who had started the tradition: "It wasn't easy for our ancestors to build these temples and put on these ceremonies, but for centuries they did. Now we want to keep it going."

As the scholar Li Lan has noted, these events were once disparaged and attacked in imperial times as debased religious practices, and in the early Communist era as "feudal superstition" (fengjian mixin). The intangible cultural heritage moniker is a protection against this. But it also functions as a way for the party to legitimize its rule-by presenting itself as the protector of these practices, it can replace the dead ideology of Marxism and the purely materialistic worldview of the post-Mao reform era. "The dramatic change in the place of Nuo in modern Chinese politics suggests a process of compromise in which the CCP has pragmatically readjusted its ideology to maximize political gain from all possible sources, including religious practices." ${ }^{, 15}$

Thus the banners around town exhorting filial piety—slogans not unlike the Communist Party's own "core socialist values" (shehuizhuyi hexin jiazhiguan). This is also why there is no contradiction between Mr. Li being a loyal party member and a pillar of this quasi-religious event; in today's China, the state has little problem with folk religious practices as long as they are at least nominally under the party's oversight.

Such policies are a significant change from the initial years of reform. Adam Chau has shown how in the 1990s and 2000s, popular religion was legitimized through careful cultivation of local ties and engaging in good works that coincided with state priorities, such as environmental protection. ${ }^{16}$ Intangible cultural heritage takes this a step further. Instead of folk religion having to ingratiate itself with the state or make its activities appear harmless, it is now openly embraced by the state.

Before leaving $\mathrm{Mr}$. Li, one question nagged at me. Who played the Yellow Demon? Was that an inherited role?

"An outsider, not someone from Guyi," he said. "He’s from another village."

"But this is the starring role," I said, thinking to myself that the person might personify evil but would it not be like playing Mephistopheles in Dr. Faustus?

"It's not a great job," Li said with a laugh. "It stinks. You'll see."

\section{The City People}

It was now 8:00 a.m., and the crowds were gathering outside the Li Family Ancestral Shrine. No one was supposed to be in the compound, but it was overrun by a group of very visible visitors—city people from neighboring Wu'an and Handan.

The biggest bloc was from the Handan Happiness Photography Club. These were wealthy people. Consider that the average disposable rural income in Hebei Province

\footnotetext{
${ }^{15} \mathrm{Li}$, Popular Religion in Modern China, op. cit. note 7, 3.

${ }^{16}$ Adam Yuet Chau, Miraculous Response: Doing Popular Religion in Contemporary China (Stanford, Calif:: Stanford University Press, 2006).
} 
was $\$ 1,527.11$ in $2014 .{ }^{17}$ And then consider the gear that some of the photographers had slung over their shoulders. One woman I saw, not atypical, was toting two Canon 5D Mark III bodies (US $\$ 4,300$ each), one outfitted with a 80-200 mm L-series lens $(\$ 1,500)$, and the other mounted with a fixed $50 \mathrm{~mm}$ lens $(\$ 1,700)$. That was $\$ 12,000$ in gear, excluding the Canon tripod, straps, and cases. She was one of the club's forty-eight members out to cover the Guyi festival, most of whom had similar gear.

Like many hobby photographers, the Happiness photographers looked unhappy, jostling for position in front of demons, or pushing people out of the way to snap pictures. After each shot, they checked, adjusted, and reshot. The goal was a perfect rendering, a ritual shot of a ritual.

It was easy to see this as exploitive, as a way for bored city people to add content to their vacuous WeChat discussion groups-something other than a selfie or a picture of dinner. This was today's ultimate travel trophy: exotic social media fodder. But for the villagers, the city people added meaning to the proceedings. The event was not being covered by journalists - as far as anyone knew, no local journalist had ever covered the ritual. And although officials came for a visit, academics were a rarity. Some had come in the early 2000s as part of the intangible cultural heritage application, but the last academic to spend any time here had been Du in 1996.

These nouveau riche photographers made up for this lack of attention in spades. When organizers tried to create some space in the courtyard for the Yellow Devil's arrival, the photographers pushed back, arguing that they had to get the shot. Finally, they simply pushed open a door that led to a stairway up to the roof, and dozens of them assembled there, setting up tripods and zoom lenses pointed down into the courtyard. I admired their tenacity. The performers, meanwhile, ate it up. They posed for the cameras, or sighed like movie stars trying to avoid the paparazzi.

And the effect was real: the photos would be posted online and circulated among friends on social media, eventually spreading around China. I had seen this countless times in my own social media groups, where amateurs publicized resurrected festivals and fairs, giving people in other parts of the country ideas about how they also could revive traditions.

While the photographers and crowd jostled for position, the phlegmatic Scout I had tried to follow was resting inside the Li family's home (see figure 4). He had been on his donkey for hours, combing the streets for the Yellow Demon, and now he sat exhausted on the side of a bed, his flags sticking up behind his back, a Peking Opera mannequin between scenes. Behind him was a new calendar touting the "China Dream." Underneath the characters "Protect the Fatherland" were the English words "Chinese Dream," and next to it in very small characters was an explanation: "The China Dream is the dream of a strong country, it is the dream of a prosperous people, it is the dream of development, it is the dream of democracy, it is the dream of a thriving great country, it is a happy dream."

Outside, the anarchy increased. In the center of the courtyard was the burned straw used to purify the hunters in the early hours of the morning. Someone had recently

${ }^{17}$ Hebei jingji nianjian [Hebei economic yearbook], "Jumin renjun kezhipei" ["Residential per capital disposable income" chart), cnki.net, http://tongji.cnki.net/kns55/navi/result.aspx?id= N2016010191\&file=N2016010191000007\&floor=1 (accessed September 26, 2016).” 


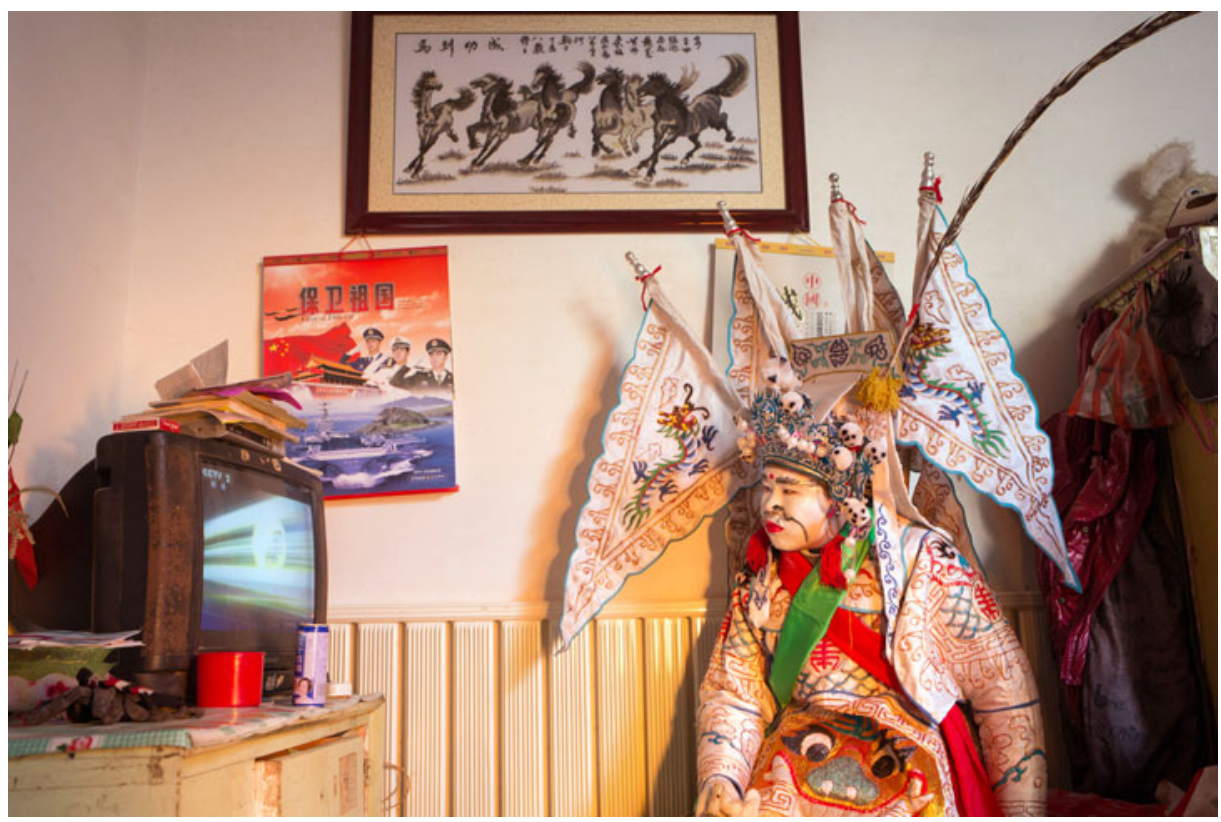

Figure 4. One of the Scouts during a break in the action. Photo by Sim Chi Yin/VII Photo Agency.

placed a rock next to the straw and tethered a black chicken to it. The bird seemed to have been crippled, because it lay on its side, its eyes blinking quickly. A man with a megaphone walked around screaming at the photographers to stand back. But they surged forward, holding up cameras to snap stills or videos of the bird and the straw.

Finally the Yellow Demon was led in, crouching under a green sheet. The sheet was removed, and he stood there pathetically, a man dressed in yellow tights, yellow sneakers, a yellow down jacket, and a yellow straw wig, and with yellow paint on his face and arms. Unlike the good demons who helped catch him, he was not a strapping physical specimen, but had spindly legs, thin arms, and a sad-sack face. Stage knives had been attached to his thighs and upper arms, making it look like people had tried to saw off his limbs but stopped part-way through. His head bowed, he was led to a stool next to the burnt straw and chicken (see figure 5).

Mr. Li stepped forward and picked up the chicken by the throat. He called the Scouts and lesser demons to witness. He quickly slit the chicken's throat. People roared, whistled, and shouted. The chicken's wings flapped as its body was held over the Yellow Demon. Mr. Li wrung the chicken so blood squirted onto the man. Now I understood why the job stank - and why he was the only performer who got paid.

The whole process lasted just three minutes, and then more straw was set afire. Two of the good demons jumped over it, and then the Yellow Demon followed suit. Cheering and yelling, the crowd followed the demons out into the streets.

The procession snaked through town, past the rows of crumbling brick homes. This could be a pretty village if the old buildings were protected and some of the eyesore concrete constructions torn down. But none of that had happened. Even the temples, which were listed on historical registers, were on the verge of collapse. One of the village's 
grandest, the Hall of the Great Buddha, was already a partial ruin. The roof had collapsed in on one wing, while another wing that had once housed an elementary school was missing a wall. A small snow drift had formed next to the blackboards.

But the ritual brought the village to life. The new banners added color. In the main square, the walls were painted with faded white-and-red characters exhorting local Communist Party officials to "Build up the Party's grassroots structure; strive for Outstanding Communist Party Cadres." Strung over it was a new red banner: "During this outstanding time, offer classical public performances, find admirers and bring the Nuo performances to the world."

About a quarter of the village's population were performing, with the rest watching. The performers were brightly dressed, in simpler versions of the brocaded silk costume that the Scouts wore. As the Yellow Demon was paraded through town, they followed, performing skits or acrobatic routines. Some were cross-dressers, which is common in traditional China — a kind of symbol of a world turned upside down, part of the anarchic, carnivalesque feeling. Two men dressed with braided wigs escorted an older man dressed like a woman. She was smoking a pipe and staggering around as if in a daze-she was supposed to be an opium addict. Another person wore a contraption that made it look like he was piggy-backing on a stuffed woman. He waved and laughed at the crowd, which played along and asked him how he was so lucky to have a wife who carried him. After them came a group of children who practiced martial arts, then a troupe of dragon dancers-men holding poles that supported a jointed wooden dragon that they could make twirls and slither in the air. Bringing up the rear was the heavy artillery: one enormous drum on a wheeled carriage. A dozen men pulled the drum, straining

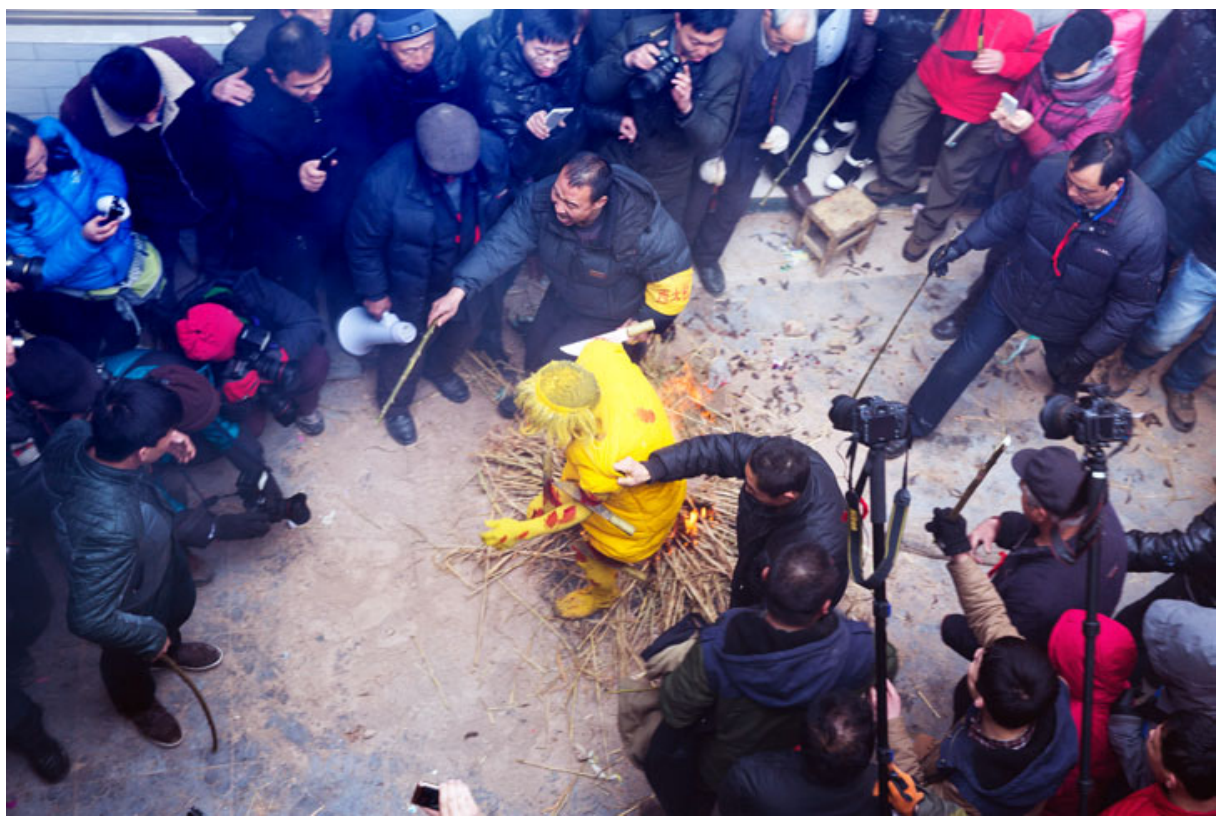

Figure 5. The Yellow Demon is led into the courtyard as photo club members jockey for position. Photo by Sim Chi Yin/VII Photo Agency. 
against their ropes. Later, they would set it up and begin a loud, rhythmic beating that reverberated through town.

The procession went east, then west, passing each temple in town, where short ceremonies took place. Slowly, the parade wound its way toward the fields that led to the highway. There, two stages had been set up on the back of flatbed trucks. One would be the court of Yama, the god of hell. His judgment was already known: death by disemboweling and beheading.

\section{The Party Secretary}

The Communist Party's representative in Guyi was Ding Jiliang, a personable forty-two-year-old who lived in the better part of town, which meant near the fields. The hilly part is far more scenic, but impassable to cars. Down in the valley, Mr. Ding could park his Volkswagen Passat out front, and be on the state road in ten minutes. That was important, because he and his family had left Guyi fifteen years ago and now lived in Handan. He commuted back here when necessary, about every week or two, mostly to solve a dispute or hold a meeting.

His home was large and spacious. Like others, it was a one-story concrete bungalow of several rooms built around an open-air courtyard. On one side were the rooms that tended to get grubby - the toilet, the kitchen, and the storage sheds - and on the other side of the courtyard were the bedrooms and the sitting room. The previous night, about a dozen of us - mostly Mr. Ding and his family_had sat around talking, drinking tea, cracking sunflower seeds, and making dumplings until midnight when I had gone to bed for a few hours. They had stayed up later and had only gone to sleep a few hours ago. Now, I opened the heavy steel door quietly, entered the courtyard, and tip-toed through to the living room.

The guests were passed out on chairs, sofas, and beds. But the secretary's wife, Wang Xiuping, roused herself from a chair and made me tea. Everyone else was asleep and did not stir, even as we sat there talking.

Mrs. Wang was a fashionable forty-three-year-old, with long black hair, thigh-high leather boots, a short tight skirt, and a mink jacket.

"Is that real?" I asked her.

"Of course it’s real! I got it in Beijing at the Dahongmen market," she said. "We go to Beijing a lot but don't come here too often."

"What's wrong with this place?"

She looked at the pressboard furnishings, the cheap sofa, the smudged curtains, and the coat of grime, then turned to me and said: "You think my home would look like this? It's just for when we come back."

She and her husband had met in a local middle school.

"In the 1980s, we didn't dare be seen with boys," she said, laughing. The only chance to meet a match had been in school. "Now you see boys and girls on the street, walking together and talking. It wasn't like that then."

The two completed middle school and began working. She labored on the family farm, and he started as a farmer too, but then began dabbling in business. I had asked 
Mr. Ding before what he did for a living, but like many Chinese he had been reticent to say much. His wife filled me in.

"He got involved in selling iron ore to smelters," she said, laughing more as she recounted his business exploits. "He failed a lot! But he's good at working and he kept at it." She kept chuckling. "He's got some abilities after all!"

Their son was born nineteen years ago, and then they had a daughter four years later. That is when the family moved to Handan, primarily for the children's education. It was a move Mrs. Wang did not like.

"I liked working in the fields. You know, you have your work and you watch the plants grow and then you harvest them. It's something nice. But he wouldn't let me plant anymore! He said, I should move to the city and look after the children. I don't know, I didn't want to move but we did and now we're city people."

That traditional view of women extended to the New Year's rituals. In this part of the village - the Great Western District—women were not allowed to participate. (For some reason, they could in the other parts of the village, but I could not get a good explanation for why this was.)

We chatted a bit more, and then her husband walked in from a side room, where he had been sleeping with other men who stayed the night. I realized that the living room had been given over to women. The room I had slept in for a few hours earlier that morning was their bedroom.

Mr. Ding was a smart-looking man, with neat hair, fashionably small, rectangular glasses, dress slacks, and a dress shirt that miraculously had not creased. He was trim and energetic, and could easily have passed for someone with a university education. He prepared for the day briskly. Like everyone else, he was roughing it, but he was not going to traipse around like me in muddy hiking books and a bulky down jacket. Instead, he polished his brown leather shoes with a piece of toilet paper. He pulled an electric razor off a ledge and gave his face a quick once-over. Then he poured hot water from a thermos into a basin, washed his face, combed his hair, brushed his teeth, polished off a bowl of dumplings, lit a cigarette, and finally sat down.

"How is the performance?" he asked politely.

I showed him a copy of David Johnson's book, Spectacle and Sacrifice.

"This mentions Guyi village? What does he say? Does he describe it much?"

I said the book explains the origins of these performances in a way that makes it seem relevant to modern-day people. It was not portrayed as something backward or oldfashioned but as something fascinating, and found in other cultures too, including the West's. I said it had brought me here.

He looked at me skeptically. I plunged forward: had he thought of making a brochure for visitors so they would know what they were seeing? There were dozens of people visiting from Handan, but they had no clue what it was all about. Maybe some of the insights from the book could help modern-day people understand what was going on.

"Why would we print a brochure? Who will pay for that?"

"It might help with tourism," I ventured doubtfully. "Maybe the government?"

"There's no money to be made from these performances. People come here and maybe buy a few things and leave. We don't have hotels here or a place for them to watch the event. Building a hotel wouldn't be worthwhile. It's a huge investment but the events are only for a few days a year. The rest of the time it'd be empty." 
It was not that Secretary Ding was oblivious to the performances' importance. As party secretary, he had overseen the expansion of a stage area, which now had seating for 500 people. But he felt fatalistic about its prospects to generate revenues.

I asked if there were any trails to go hiking. What if this were the base for a local tourism industry, with bed-and-breakfast homes? The village itself, if the temples were fixed up and the streets cleared, was really attractive. I mentioned going to Kinmen Island in Taiwan. It had been a Cold War flashpoint with bunkers and barbed wire. But now it had been turned into a national park.

“There's nothing natural nearby. That's all up further into the mountains. Here it's pretty flat, and most of what we have is industry. You don't want to hike here or go for a walk! You'll hit a coking factory over the next hill. Who wants to see that?"

He laughed. Talking to me was interesting but a waste of time. He said he had to head off to take care of things and departed quickly, dragging a friend out of bed from the side room.

"We don't come here that often so when we're here, he's busy," his wife explained. "He was elected party chief three years ago, and it's basically just a burden. This or that dispute to handle, and what good does it do our business? But he's trying hard."

A few days later in Handan, I mentioned Mr. Ding's bifurcated life to a friend who is also in the Communist Party. I said it seemed strange that the local party secretary did not live in the village. My friend disagreed.

"For the people in the village, having a party secretary who's a successful businessman in the nearby town is a great thing," he said. "If their sons or daughters make it into a city school, he can help them, and he will understand the bureaucracy better than someone who's never lived in the city."

I mulled that over and thought he was right; the Guyi party secretary was a powerful lobbyist where it mattered. Like organizing the Nuo drama, most local matters could take care of themselves.

By now the house had woken up. Three women were on social media, sending notes to their friends, while two boys played a game on a handheld device. I asked Mrs. Wang what business her husband had rushed off to handle.

"The deputy party secretary for the county has come by to see the performance. He's only here for a couple of hours and just arrived. Ding has gone to escort him around town."

Another official here to tout his role as a promoter of traditional culture. I had to get out before the Yellow Demon was disemboweled.

\section{JUSTICE}

The field south of town had been covered with a light dusting of snow when I had arrived the day before, and was empty but for two trucks parked about 100 yards apart at right angles. They were mobile stages, with frames lashed to their flatbeds and a tent made of tubular steel and laminated canvas. The canvas was painted with terrifying scenes from the underworld. Mostly they involved evil people being punished by demons: disemboweled alive, tongues pulled out by metal tongs, burned at the stake, 
impaled on beds of metal spikes, tossed into rivers of fire, sawed in half with a two-demon saw.

Now the field had morphed into a muddy sea. The mobile stages were surrounded by people. Hawkers had set up shop on the road next to the field, offering everything one might need at the execution of a demon: cotton candy, sliced pineapples, sausages, yardlong sugarcane stalks to suck on, and heaps of cheap plastic toys: BB-guns, yo-yos, and badminton sets, each for under a dollar.

The road was a good five feet higher than the field, and people lined the edge, looking down at the muddy bowl. Police tried to keep a space free in front of the two stages for the performers, who would arrive sometime soon. But the crowd kept growing and pushing the police back, who would stand firm and yell at the crowd to take a step or two back. It was a constant back and forth. I admired the patience of the police, but it also seemed absurd: police trying to keep one mob at bay so that another horde could lynch a demon.

I made my way down to the field and waited for the show. The sun was out, and the blue sky began to push through the industrial haze, but it was still cold and people were bundled up in colorful down jackets and woolen hats. Many of the women seemed to be back from the big city: they had short frizzy hair, often dyed red or orange. Meanwhile, the urban adventurers had massed on the other side of the field, waving big red flags with white characters: "Handan City Happiness Photo Club," "China Motorcycle Club," and "Specialized Bicycle Club," the latter named after a high-end U.S. brand.

I pulled out an official Chinese government-issued press pass and tried to get closer to the stages, but the police shook their heads. Then I noticed members of the Happiness Photo Club wandering the field beyond the police line, jabbing telephoto lenses into people's faces. One member was dressed in a matching red jacket and snow pants with a red baseball hat decorated with the word "Coco." She gingerly picked her way through the muddy field, taking pictures of locals and the stage. Their credentials seemed to matter more-and maybe they did. Their photos on social media would be distributed thousands of times, helping to spread ideas about tradition around China. What could I offer?

Then the music started, drums and cymbals, a simple steady pulsing that added to the sense of impending doom. On every fourth drumbeat, the cymbals crashed, a primal music that seemed to match the pulsing of our blood. We began swaying to the beat.

The actors assembled on the two stages. On one was Yama, the god of Hell, who sat on a throne. He wore a papier-mâché mask with fierce golden eyes that seemed to pop out of his head. He stared at the proceedings but took no direct part. On the other stage was Panguan, the Judge of the Underworld, flanked by men with animal heads and bright robes embroidered with dragons. The power of these performers was palpable: these were no statues or paintings but living people-as if the gods had entered our realm to restore order.

Then the mob arrived with yells and cries, filling the space in front of the stages that the police had kept clear. The men carried willow branches, and drove the Yellow Demon toward Panguan. The crowd surged, and the police fell back, desperately trying to keep order. A village elder barked out orders on a megaphone, a twisted snarl of feedback that no one could understand. The police glumly locked arms and tried to protect the stage. 
The Happiness photographers pushed to the front, desperately firing off their cameras over their heads, as if on the most crucial of assignments. One frame, any frame, was essential. The Yellow Demon was held by ropes around his neck and pushed toward Panguan the judge. Panguan read the foreordained verdict, incomprehensible amid the gongs, cymbals, and shouting.

The mob surged back and forth and finally pushed the demon toward a gallows that had been set up on the far end of the field. The speakers screeched as the vanguard reached the stage. There were shouts and yells as the Yellow Demon was dragged to the stage. Smudge pots belched out smoke, shrouding the men on stage (see figure 6).

The good demons - the ones who had hunted the Yellow Demon through the early morning hours-jumped on a raised platform on the stage, screaming and waving knives, clubs, and daggers. Smoke covered them and then blew away, revealing one of them shaking a bloody handful of meat - the demon had been disemboweled!

The crowd yelled. Willow branches were thrust in the air. The photographers swung their cameras over their heads like morning stars, wildly firing off thousands of frames. More smoke and a yell from the stage: the good demon waved the head of the Yellow Demon-he had been beheaded! Screams and yells of approval, and then nothing. The smoke cleared. The Yellow Demon has disappeared.

The crowd calmed. People took a deep breath, looked around, laughed, and then began walking back to the village and the snack stands. Order and harmony had been restored. The moon year could begin.

I walked up to the gallows. It was a wooden stage that had a trapdoor. Through wooden slats I could see under the stage. The Yellow Demon stood on the muddy

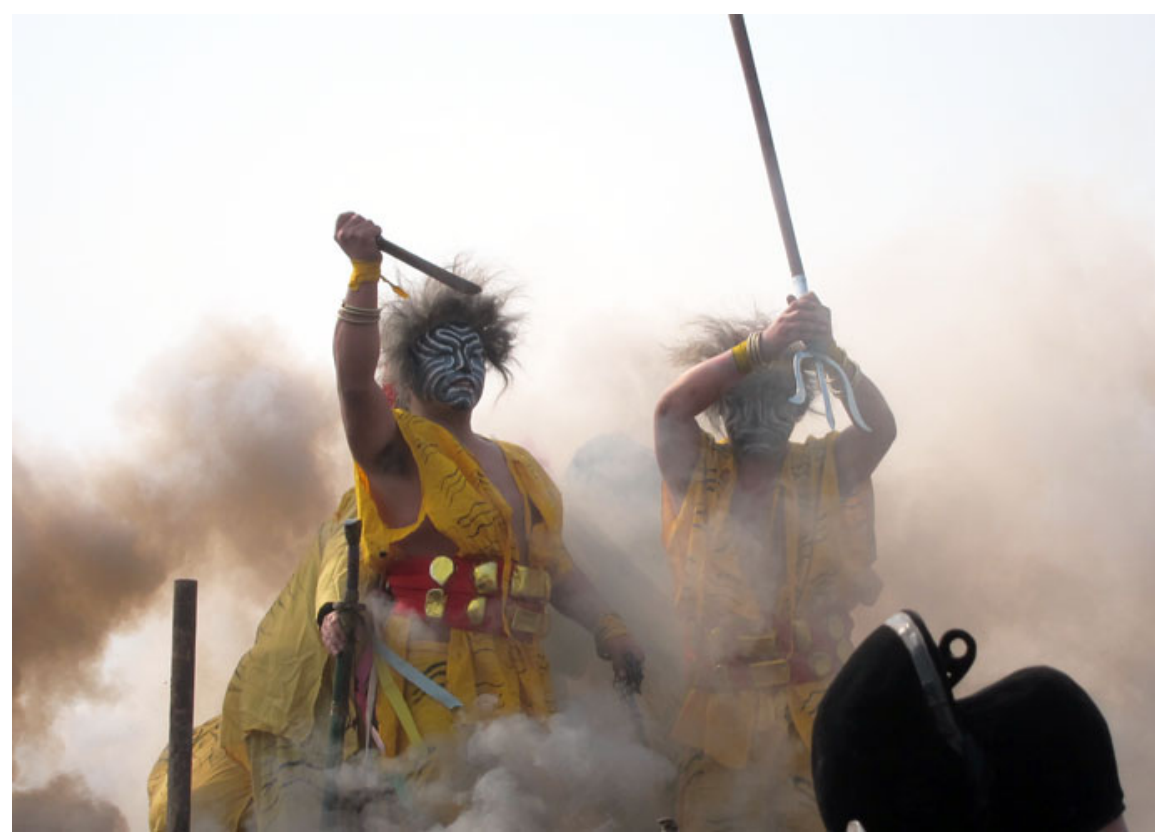

Figure 6. Two good demons slay the Yellow Demon at the culmination of the ceremony. Photo by Sim Chi Yin/VII Photo Agency. 


\section{Ian Johnson}

ground with a wry smile. He slowly pulled off the stage knives embedded in his limbs and rubbed his skin. One of the village elders handed him an envelope stuffed with cash, and a cigarette. Another man draped an army greatcoat over his shoulders. The demon carefully pocketed the money and took a long drag on the cigarette.

The men were silent, waiting for the crowd to disperse before leaving their sanctuary. The Yellow Demon changed into ordinary clothes and tried to rub the makeup off his face. Eventually, one of the Guyi elders held up the green sheet and the Yellow Demon nodded, tossing his cigarette in the mud. He crouched down, and the sheet was thrown over him. Two men took him by the elbows and led him out to a waiting van, which would take him over the mountains and back to his home in another village.

\section{Acknowledgments}

I would like to thank Jeffrey Wasserstrom for encouraging me to write this piece, the photographer Sim Chi Yin of the VII Photo Agency for accompanying me and taking the photos, and two anonymous reviewers for helpful input. Thanks also to Philip Clart of Leipzig University and Mayfair Mei-Hui Yang of the University of California, Santa Barbara, for reading drafts. 